\title{
Preface
}

In 1971 Congress passed a Comprehensive Child Development Bill that authorized some two billion dollars for childcare services. The bill was vetoed by then-President Nixon, with an accompanying veto message that has since come to be regarded as one of the more remarkable documents of American social policy. The message read, in part:

... our response to this challenge [child development] must . . . be consciously designed to cement the family in its rightful position as the keystone of our civilization. . . . Good public policy requires that we enhance rather than diminish both parental authority and parental involvement with children. . . .

. . . for the Federal government to plunge headlong financially into supporting child development would commit the vast moral authority of the National Government to the side of communal approaches to childrearing over against the family-centered approach.

This President, this government, is unwilling to take that step. ${ }^{1}$

In the period since 1971, these political objections to federal support of childcare have been overshadowed by economic ones. The problems of inflation and recession, and the resulting cutbacks in social services, have temporarily blunted the hopes of childcare advocates for new federal legislation. Childcare activity in the first half of the 1970s might best be characterized as a holding action; much of the effort of childcare forces has been directed toward protecting existing programs from Administration attempts at retrenchment.

Nevertheless, the conditions that prompted the 1971 bill are still very much with us. The number of families headed by women with children continues to rise dramatically; over the past decade such families may have increased at almost ten times the rate of two-parent families. ${ }^{2}$ The

1. Richard Nixon, "Veto Message-Economic Opportunity Amendments of 1971."

2. Heather L. Ross and Isabel V. Sawhill, Time of Transition: The Growth of Families Headed by Women, pp. 1-2. 
eagerness of both single and married mothers of young children to work outside the home has not diminished; mothers of preschool and schoolage children are acknowledged to account for much of the recent growth in female labor-force participation. ${ }^{3}$ And the number of existing childcare facilities continues to be grossly inadequate; it is estimated that for the six million children under the age of six with working mothers, there are only one million licensed daycare places. ${ }^{4}$

These circumstances, combined with the continued spread of political consciousness among women, have kept the childcare issue alive-if not terribly well - in an area of austerity. It is reasonable to assume that an increased federal role in childcare is still on the national agenda. But the problems raised by governmental involvement in childcare go beyond the issue of economic feasibility. ${ }^{5}$ The Nixon veto message reflects the political dynamite inherent in any attempt to construct a national childcare "policy"; and recent efforts to secure childcare legislation, in spite of their obviously dim prospects, have been met by an unusually vitriolic and anonymous smear campaign. ${ }^{6}$ But for those involved in the childcare movement, the most important issue at this time is one of internal politics: who shall control the delivery of childcare? If federal funds for new preschool programs were made

3. A. H. Raskin, "The Changing Face of the Labor Force," New York Times, February 15, 1976, p. 4; and Elizabeth Waldman, "Children of Working Mothers, 1974." Waldman points out the rise in the number of children with working mothers despite the falling birthrate (p. 64): "Since 1970, the number of children whose mothers were in the labor force has risen by 1.2 million, while the number of all children in families has dropped by 2.2 million."

4. U.S. Senate, Committee on Finance, Child Care Data and Materials, pp. 58-59. This figure refers to slots in daycare centers and family daycare homes. It does not include other arrangements for preschool children that are defined as "educational" and are typically half-day programs, such as kindergartens, nurseries, and Headstart programs. Latest figures available on enrollment in these "educational" programs show a participation of 76.1 percent of all five-year-olds in the U.S., 33.5 percent of four-year-olds, and 15.5 percent of three-year-olds. Linda Barker, "Preprimary Enrollment: October 1972," p. 3.

5. Estimates of the cost of providing additional childcare slots are provided by Abt Associates, A Study in Child Care, Vol. III: Cost and Quality Issues for Operators, Day Care and Child Development Council of America, "Standards and Costs for Day Care;" Mary Potter Rowe and Ralph D. Husby, "Economics of Child Care: Cost, Needs, and Issues;" U.S. Senate, Committee on Finance, Child Care Data and Materials; and Dennis R. Young and Richard R. Nelson, Public Policy for Day Care of Young Children.

6. Congressman Thomas P. O'Neil, "The Vicious and Dishonest Campaign against the Child and Family Services Bill," Congressional Record, Vol. 121, n. 175, December 1, 1975, H11552-H11559. 


\section{Preface xi}

available tomorrow, under whose auspices would such programs be offered? The major struggle is between the American Federation of Teachers and its allies and a coalition of other professional and community groups. The AFT argues that exclusive control of new programs should be given to the public schools; opponents want to preserve and promote more diversified sponsorship.

I hope that this book will contribute to informed debate on childcare policy. By offering a close look at one example of educationally defined childcare delivered through public schools, it may help in evaluating the claims of opposing factions within the childcare movement. I hope that it will also provide a concrete basis for approaching two larger, more fundamental questions raised by childcare: the professionalization of childcare services, and the relationship of childcare systems to family life. 